\title{
IDENTIFIKASI CERITA PADA RELIEF NARATIF DI CANDI SUKUH
}

\section{Tale Identification of Narrative Reliefs in Candi Sukuh}

\author{
Radila Adwina $^{1)}$ dan Agi Ginanjar ${ }^{2)}$ \\ ${ }^{1)}$ Balai Arkeologi Jawa Barat \\ Jl. Raya Cinunuk km.17, Cileunyi, Bandung \\ Email: radiladwina@gmail.com \\ ${ }^{2)}$ Program Studi Arkeologi, FIB, Universitas Indonesia \\ J1. Margonda Raya, Pondok Cina, Kecamatan Beji, Kota Depok, Jawa Barat \\ Email: agi.ginanjar62@yahoo.com
}

Naskah diterima: 18 Maret 2019 Revisi terakhir: 24 Juni 2019

Disetujui terbit: 15 Juli 2019 - Tersedia secara online: 30 Juli 2019

\begin{abstract}
Candi Sukuh is a sacred temple complex shaped like step-pyramid structure with three terraces, which was used on late period of Majapahit Kingdom, around 15th century. Every terrace is decorated with various reliefs, either ornamental reliefs or narrative reliefs. The tale of the narrative reliefs had been studied by some researchers, but they had different opinion about it. There are also allegations on the tale from those reseachers of some other narrative reliefs, and narrative reliefs that have never been studied before. There are 13 carved stones of those narrative reliefs, with one or more panels on each stone. Each relief may consist of various relief components, such as figures, animals, plants, buildings, weapons, and other things. Those components are compared with other studies of relief on Majapahit period to obtain early identifications of the relief. After that, each component is arranged to form 18 tale scenes. The scenes are compared with Ancient Javanese texts or other sacred building reliefs from Majapahit period, so that the source of the tale and particular scene of the tale are identified.
\end{abstract}

Keywords: Relief, Candi Sukuh, identification.

\begin{abstract}
Abstrak
Candi Sukuh merupakan kompleks bangunan suci berbentuk punden berundak dengan tiga teras, yang digunakan pada masa akhir Kerajaan Majapahit, yaitu abad ke-15 M. Setiap teras dihias dengan berbagai relief, baik relief hiasan maupun relief naratif. Penelitian terhadap cerita pada relief-relief naratif tersebut telah dilakukan oleh beberapa peneliti, namun mereka menafsirkan cerita yang berbeda-beda. Selain itu terdapat pula relief naratif yang ceritanya masih berupa dugaan peneliti sebelumnya atau belum pernah diteliti sama sekali. Relief-relief tersebut terbagi ke dalam 13 batu berelief dengan jumlah panil yang berbeda pada tiap batu. Tiap relief disusun dari komponen relief, yang dapat terdiri dari komponen tokoh, binatang, tumbuhan, bangunan, senjata, dan benda lain. Setelah itu, masing-masing komponen disusun sehingga menghasilkan 18 adegan cerita, yang kemudian dibandingkan dengan karya sastra Jawa Kuno ataupun relief bangunan suci masa Majapahit lainnya, sehingga dapat diketahui sumber cerita dan adegan tertentu dalam cerita yang sama dengan penggambaran relief.
\end{abstract}

Kata kunci: Relief, Candi Sukuh, identifikasi. 


\section{PENDAHULUAN}

Relief adalah gambaran dalam bentuk ukiran yang dipahat. Dalam suatu candi, relief mengandung suatu arti atau melukiskan peristiwa atau cerita tertentu (Ayatrohaedi dkk., 1981: 80). Berdasarkan jenisnya, relief terbagi menjadi dua, yaitu relief hiasan yang merupakan relief yang tidak mengandung cerita tertentu, dan relief naratif yang mengandung cerita tertentu (Satari, 1999: 3-6).

Hanya beberapa cerita dalam karya sastra yang berasal dari India maupun Jawa Kuno yang dipilih oleh para seniman untuk dijadikan relief (Munandar, 2004: 54). Di antara cerita-cerita tersebut, terdapat relief yang hanya menggambarkan suatu adegan atau peristiwa tertentu yang diharapkan dapat mewakili keseluruhan cerita yang biasanya disebut sebagai relief adegan pandu (leitmotiv relief) (Munandar, 2011: 216217).

Relief dengan adegan pandu terpahatkan pada beberapa candi. Beberapa adegan cerita sudah teridentifikasi, salah satunya adalah cerita Sri Tanjung. Cerita tersebut menggambarkan adegan seorang putri (Sri Tanjung) sedang menaiki seekor lumbalumba. Salah satunya terpahatkan di dinding Candi Surawana (Munandar, 2011: 197199). Selain itu ada juga adegan yang belum dapat dipastikan ceritanya, seperti reliefrelief yang berada di Candi Sukuh. Selain relief dengan adegan pandu, di Candi Sukuh terdapat pula relief naratif bukan adegan pandu yang belum teridentifikasi ceritanya.

Candi Sukuh terletak di Kecamatan Ngargoyoso, Kabupaten Karanganyar, Provinsi Jawa Tengah. Kompleks candi berbentuk punden berundak yang mempunyai tiga teras dengan arah hadap ke barat. Berdasarkan sengkalan memet, yaitu angka tahun yang dinyatakan dengan gambar atau lukisan (Magetsari dkk., 1979: 43), pada gapura candi yang menunjukkan tahun 1359 Śaka atau 1437 Masehi, Candi Sukuh masih digunakan pada masa akhir Majapahit (Crucq, 1936: 337-338).

Usaha untuk mengetahui cerita yang ada pada relief-relief tersebut telah dilakukan oleh sejumlah peneliti. Usaha tersebut menghasilkan beberapa persamaan dan perbedaan pendapat mengenai cerita pada relief. Persamaan pendapat terdapat pada cerita Sudamala yang dipahatkan pada lima panil lepas yang terletak di halaman bagian utara teras III dan satu panil yang terletak pada batur bagian utara teras III (Kempers, 1959: 103; Padmapuspita, 1981: 144, 150-158; Sedyawati dkk., 2013: 193; Stutterheim, 1930: 15-17; Suhadi dkk., 2000: 9). Selain itu, terdapat pula cerita Garudeya yang terpahatkan pada dua tiang (pilar) yang terletak di bagian barat batur bagian utara teras III (Kempers, 1959: 102; Padmapuspita, 1981: 142; Stutterheim, 1930: 21-22; Suhadi dkk., 2000: 10). Persamaan pendapat lainnya merupakan relief yang menggambarkan kegiatan pandai besi pada bagian selatan teras II (Kempers, 1959: 103; Sedyawati dkk., 2013: 193). Pada relief pandai besi tergambar bervariasi alat perlengkapan yang dapat ditemukan dalam Tantu Panggelaran dan naskah-naskah lontar dan tradisi di Bali (Subroto, 1977).

Selain tiga persamaan pendapat tersebut, terdapat juga perbedaan pendapat para peneliti terhadap relief yang lain. Yang pertama, pada relief berbingkai kala-mrga yang berada di sisi barat obelisk (tiang segi empat meruncing ke ujung) batur bagian utara, 
menurut Stutterheim (1930: 24), relief tersebut menggambarkan Bima dengan Batara Guru, yang oleh Suhadi dkk. (2000: 11) pernyataan tersebut disimpulkan sebagai cerita Nawaruci. Pada pendapat selanjutnya, Stutterheim (1956: 120-123) menyatakan bahwa relief tersebut menggambarkan cerita Bhima Bungkus dan Bhimaswarga. Sementara Padmapuspita (1981: 128-129) menyebutkan relief tersebut ada yang menafsirkan sedang menggambarkan pertemuan Bima dengan Dewa Ruci di cerita Nawaruci atau Sadewa bertemu dengan Siwa di cerita Sudamala. Yang kedua, pada relief-relief yang menghiasi keempat sisi candi kecil yang terletak di sebelah barat candi induk, menurut Padmapuspita (1981: 133), relief pada sisi barat menggambarkan cerita Sudamala, sedangkan menurut Santiko (1995: 133), relief pada candi kecil tersebut mungkin berasal dari cerita Bhimastawa kemudian Santiko (2011: 19) menyebutkan bahwa candi kecil tersebut menggambarkan cerita Bhimaswarga, lalu menurut Zoetmulder (1983: 369) relief pada sisi selatan merupakan adegan dari cerita Smaradahana, dan terakhir menurut Sedyawati dkk. (2013: 193) relief pada candi kecil tersebut menggambarkan cerita Bhimaswarga.

Selain relief-relief yang telah disebutkan, Stutterheim (1930: 24) juga menyebutkan salah satu pilar yang menggambarkan Arjuna dan panakawan yang sedang membawa gong, kemudian Suhadi dkk. (2000: 10) menyebutkan bahwa relief Arjuna tersebut kemungkinan bagian dari cerita Bharatayuddha. Pada obelisk, Suhadi dkk. (2000: 11) menyebutkan adanya kemungkinan penggambaran bagian cerita Arjunawiwaha, dan Sedyawati dkk. (2013: 191) menyatakan bahwa terdapat cerita Garudeya, Samudramanthana, dan adegan dengan tokoh Hanuman.

Terdapat pula relief-relief lepas di halaman bagian utara teras I, relief pada umpak-umpak batu di halaman bagian utara teras III, dan relief pada sebuah tiang di sebelah barat batur bagian selatan teras III yang belum teridentifikasi. Seperti yang telah diuraikan sebelumnya, terdapat relief-relief yang mengandung adegan cerita namun belum teridentifikasi dan yang belum dapat dipastikan ceritanya karena adanya perbedaan pendapat oleh beberapa peneliti atau yang belum disebutkan dalam penelitian lain. Berdasarkan hal tersebut maka permasalahan yang dapat diajukan pada penelitian ini adalah bersumber dari cerita apakah relief-relief naratif pada Candi Sukuh yang belum teridentifikasi?

Sumber data terdiri dari 13 batu berelief naratif, yaitu tiga batu berelief yang terletak pada bagian utara halaman teras I, dan sepuluh batu berelief yang terletak pada teras III (lihat Gambar 1). Batu berelief tersebut merupakan relief yang memiliki perbedaan pendapat pada cerita, yang belum diidentifikasi, dan yang belum disebutkan dalam penelitian lain. Setiap batu berelief memiliki jumlah panil yang berbeda. Masingmasing panil batu berelief tersusun dari komponen-komponen relief yang merupakan data utama penelitian. Sementara naskah cerita Jawa Kuno serta komponen dan adegan relief serupa di bangunan suci lain yang semasa merupakan data sekunder yang membantu dalam mengidentifikasi cerita pada relief.

Tahapan penelitian menggunakan empat dari tujuh tahapan yang dikemukakan oleh Sharer \& Ashmore (2003: 155-160), yaitu (1) formulasi, dengan mengumpulkan 
dan mempelajari riwayat dan laporan penelitian, artikel, serta buku mengenai reliefrelief Candi Sukuh, relief-relief masa Majapahit secara umum, serta naskah-naskah karya sastra Jawa Kuno; (2) pengumpulan data, dengan mengamati serta melakukan pengukuran dan perekaman sumber data dan data utama secara verbal maupun piktorial, mengumpulkan data sekunder dengan melakukan perekaman secara langsung ataupun melalui laporan penelitian, artikel, dan buku; (3) analisis, melakukan analisis awal dengan mengidentifikasi data sesuai dengan ciri-ciri komponen relief pada relief-relief Majapahit yang telah diteliti, kemudian mengelompokkan hasil identifikasi awal tersebut ke dalam beberapa kategori besar, yaitu komponen tokoh, binatang, tumbuhan, bangunan, senjata, dan benda berbentuk tidak beraturan, elips, segiempat, serta bulat. Kemudian dengan menganalisis secara kontekstual data-data yang telah diidentifikasi awal, yaitu masing-masing komponen relief dalam suatu panil dihubungkan dan disusun sehingga menghasilkan sebuah konteks adegan yang kemudian dibandingkan dengan adegan relief masa Majapahit lain dan adegan pada naskah-naskah cerita yang berkembang pada masa itu; dan (4) interpretasi, yaitu hasil perbandingan yang dilakukan pada tahap analisis menghasilkan relief yang dapat diidentifikasi ataupun yang tidak dapat diidentifikasi, serta sumber cerita yang digambarkan pada relief yang dapat diidentifikasi tersebut.

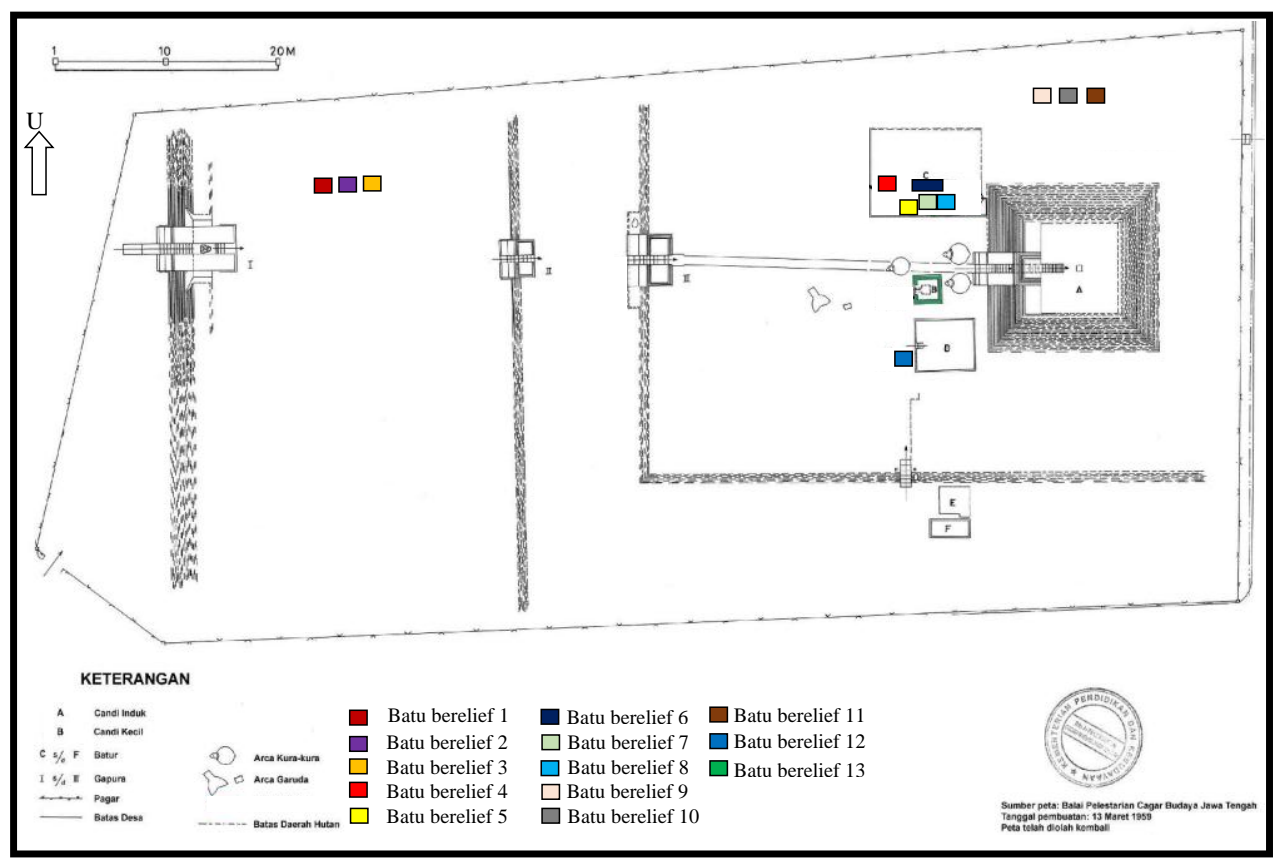

Gambar 1. Denah Keletakan Batu Berelief (Sumber: Dokumen BPCB Jawa Tengah, 1959, telah diolah kembali)

\section{HASIL DAN PEMBAHASAN}

\section{Komponen Relief}

Komponen relief merupakan bagian-bagian dari relief yang menyusun keseluruhan relief naratif. Masing-masing panil dari 13 batu berelief memiliki variasi komponen yang berbeda dan dapat terdiri dari satu komponen atau lebih. Seluruh komponen dibagi menjadi sembilan kategori besar, yaitu komponen tokoh, komponen 
binatang, komponen tumbuhan, komponen bangunan, komponen senjata, komponen benda berbentuk seperti pilar pendek, berbentuk elips, berbentuk segiempat, dan berbentuk bulat.

Kategori besar pertama yaitu komponen tokoh dibagi dalam enam kategori yang lebih kecil berdasarkan jenis, jenis kelamin, penampilan berdasarkan busana dan perhiasan, benda yang dibawa, tunggangan yang dinaiki, serta sikap tubuh yang ditunjukkan. Enam kategori komponen tokoh tersebut memiliki ciri yang lebih rinci. Tidak semua panil pada 13 batu berelief memiliki ciri komponen tokoh yang sama (Tabel Jumlah Kemunculan Komponen Tokoh pada Tiap Panil Batu Berelief lihat Lampiran 1).

Komponen binatang dibagi dalam sebelas kategori kecil berdasarkan binatangbinatang yang terpahatkan, yaitu kerbau, kambing, babi, ular, badak, harimau, rusa, burung, kepiting yuyu, kadal, dan capung. Komponen binatang digambarkan pada tujuh batu berelief (lihat Tabel 1). Terdapat batu berelief yang pada seluruh panilnya menggambarkan komponen binatang tanpa komponen tokoh seperti batu berelief 2 .

Tabel 1. Jumlah Kemunculan Komponen Binatang pada Tiap Panil Batu Berelief

\begin{tabular}{|c|c|c|c|c|c|c|c|c|c|c|c|c|c|c|c|c|}
\hline \multirow[b]{2}{*}{$\begin{array}{l}\mathbf{N} \\
\mathbf{o}\end{array}$} & \multirow[b]{2}{*}{ Komponen Binatang } & \multirow{2}{*}{$\begin{array}{c}\text { BB } \\
2\end{array}$} & \multicolumn{2}{|c|}{ BB 3} & \multirow{2}{*}{$\begin{array}{c}\text { BB } \\
6\end{array}$} & \multirow{2}{*}{$\begin{array}{c}\text { BB } \\
7\end{array}$} & \multicolumn{2}{|c|}{ BB 8} & \multicolumn{4}{|c|}{ BB 10} & \multicolumn{4}{|c|}{ BB 11} \\
\hline & & & P.A & P.B & & & P.A & P.B & P.A & P.B & P.C & P.D & P.A & P.B & P.C & P.D \\
\hline 1 & Kerbau & 4 & & & & & & & & & 3 & 2 & & & & \\
\hline 2 & Kambing & & & & 1 & & & & & & & & & & & \\
\hline 3 & Babi & & & & 1 & & & 1 & & & & & & & & \\
\hline 4 & Ular & & & & & 1 & & & & & & & & & & \\
\hline 5 & Badak & & & 2 & & & & & & & & & & & & \\
\hline 6 & Harimau & & & & & & & 1 & 1 & & & & & & & \\
\hline 7 & Rusa & & & & & & & 3 & & & & & & & & \\
\hline 8 & Burung & & & & & & & 2 & & 1 & & & 1 & & & \\
\hline 9 & Kepiting Yuyu & & & & & & & & 1 & & & & & & & \\
\hline 10 & Kadal & & & & & & & & 2 & & & & & & & \\
\hline 11 & Capung & & & & & & & & & 1 & & & & & & \\
\hline
\end{tabular}

Keterangan: BB: Batu Berelief; P.: Panil

Komponen tumbuhan terbagi dalam dua kategori yang lebih kecil yaitu berdasarkan bentuk dan tempat tumbuh. Tumbuhan berdasarkan bentuk meliputi pohon dan semak-semak. Sementara tumbuhan berdasarkan tempat tumbuh meliputi alami dan pot. Komponen tumbuhan digambarkan pada enam batu berelief (lihat Tabel 2). 
Tabel 2. Jumlah Kemunculan Komponen Tumbuhan pada Tiap Panil Batu Berelief

\begin{tabular}{|c|c|c|c|c|c|c|c|c|c|c|c|c|c|c|c|c|c|c|c|c|c|c|c|c|c|c|}
\hline \multirow{3}{*}{$\begin{array}{l}\mathbf{N} \\
\mathbf{o}\end{array}$} & \multirow{3}{*}{$\begin{array}{l}\text { Komponen } \\
\text { Tumbuhan }\end{array}$} & \multicolumn{2}{|c|}{ BB 4} & \multicolumn{4}{|c|}{ BB 5} & \multicolumn{2}{|c|}{\begin{tabular}{|l|} 
BB 8 \\
\end{tabular}} & \multicolumn{4}{|c|}{ BB 10} & \multicolumn{3}{|c|}{ BB 12} & \multicolumn{10}{|c|}{ BB 13} \\
\hline & & P. & P. & P. & P. & P. & P. & P. & P. & P. & P. & P. & $\mathbf{P}$. & $\mathbf{P}$. & P. & $\mathbf{P}$. & P. & P. & P. & P. & P. & P. & P. & P. & P. & $\mathbf{P}$. \\
\hline & & $\mathbf{A}$ & B & $\mathbf{A}$ & B & $\mathrm{C}$ & D & $\mathbf{A}$ & B & $\mathbf{A}$ & & & D & $\mathbf{A}$ & $\mathbf{B}$ & C & $\mathbf{A}$ & B & $\mathbf{C}$ & D & $\mathbf{E}$ & $\mathbf{F}$ & & & $\mathbf{I}$ & $\mathbf{J}$ \\
\hline \multirow[t]{3}{*}{1} & Bentuk: & & & & & & & & & & & & & & & & & & & & & & & & & \\
\hline & Pohon & & & & 1 & & & 4 & 8 & 1 & & & & 1 & 1 & 2 & & 1 & 1 & 1 & & 1 & 1 & & & \\
\hline & Semak-semak & 1 & 1 & & & & & & 1 & & & & & & & & & & & & & & & & & \\
\hline \multirow[t]{3}{*}{2} & Tempat tumbuh: & & & & & & & & & & & & & & & & & & & & & & & & & \\
\hline & Alami & 1 & 1 & & 1 & & & 4 & 9 & 1 & & & & 1 & & 1 & & & 1 & & & 1 & & & & \\
\hline & Pot & & & & & & & & & & & & & & & 1 & & 1 & & & & & & & & \\
\hline
\end{tabular}

Keterangan: BB: Batu Berelief; P.: Panil

Komponen bangunan terdiri dari empat kategori yang lebih kecil, yaitu berdasarkan dinding, atap, kaki, dan dengan pagar keliling. Masing-masing kategori komponen bangunan memiliki ciri yang lebih rinci. Bangunan berdasarkan dinding meliputi bangunan terbuka dan bangunan tertutup. Bangunan berdasarkan atap meliputi atap limasan, atap tajuk, dan tanpa atap. Bangunan berdasarkan kaki meliputi tiang dengan umpak, tiang dengan batur, dan tanpa tiang. Bangunan dengan pagar keliling memiliki pagar yang dihias bilah tombak di bagian atasnya dan sebuah roda besar (lihat Tabel 3).

Tabel 3. Jumlah Kemunculan Komponen Bangunan pada Tiap Panil Batu Berelief

\begin{tabular}{|c|c|c|c|c|c|c|c|c|c|c|c|c|c|c|c|c|c|c|c|}
\hline \multirow[b]{2}{*}{$\begin{array}{l}\mathbf{N} \\
\mathbf{o}\end{array}$} & \multirow[b]{2}{*}{ Komponen Bangunan } & \multicolumn{2}{|c|}{ BB 4} & \multirow{2}{*}{$\begin{array}{c}\text { BB } \\
7\end{array}$} & \multicolumn{2}{|c|}{ BB 8} & \multicolumn{3}{|c|}{ BB 12} & \multicolumn{10}{|c|}{ BB 13} \\
\hline & & P.A & P.B & & P.A & P.B & P.A & P.B & P.C & P.A & P.B & P.C & P.D & P.E & P. F & P.G & P.H & P. I & P. J \\
\hline \multirow{3}{*}{1} & Dinding: & & & & & & & & & & & & & & & & & & \\
\hline & Terbuka & 1 & & 1 & & 3 & & 1 & & & & & & & & 1 & & & \\
\hline & Tertutup & & & & 1 & & & & & & & & & & & & & & \\
\hline \multirow{4}{*}{2} & Atap: & & & & & & & & & & & & & & & & & & \\
\hline & Limasan & & & & & 3 & & & & & & & & & & 1 & & & \\
\hline & Tajuk & & & 1 & 1 & & & & & & & & & & & & & & \\
\hline & Tanpa atap & & & & & & & 1 & & & & & & & & & & & \\
\hline \multirow{4}{*}{3} & Kaki: & & & & & & & & & & & & & & & & & & \\
\hline & Tiang dengan umpak & 1 & & & 1 & & & 1 & & & & & & & & & & & \\
\hline & Tiang tanpa umpak & & & 1 & & & & & & & & & & & & & & & \\
\hline & Tanpa tiang & & & & & 2 & & & & & & & & & & 1 & & & \\
\hline 4 & Dengan pagar keliling & & & & 1 & & & & & & & & & & & & & & \\
\hline
\end{tabular}

Keterangan: BB: Batu Berelief; P.: Panil

Komponen senjata merupakan senjata yang tidak dibawa oleh tokoh. Senjatasenjata tersebut meliputi tombak, perisai, dan pedang yang digambarkan dalam satu panil dalam dua batu berelief. Batu berelief 1 menggambarkan lima senjata tombak dan panil B batu berelief 5 menggambarkan tiga jenis senjata meliputi tombak, perisai, dan pedang.

Empat kategori besar selanjutnya merupakan kategori yang memiliki komponen benda dengan bentuk yang berbeda-beda. Komponen benda berbentuk pilar pendek terdapat benda seperti mangkuk di atasnya pada panil B batu berelief 8 . Komponen 
benda berbentuk elips tergeletak secara horisontal dengan bagian atas memiliki bentuk segitiga kecil, serta dua garis horisontal di bawah benda elips tersebut pada panil B batu berelief 8 . Komponen benda berbentuk segiempat terletak di bagian bawah panil dan di atasnya terdapat kepala seorang tokoh pada panil 13 batu berelief 13 . Komponen benda berbentuk bulat memiliki garis berbentuk tanda tambah (+) di dalamnya pada panil A batu berelief 11 .

\section{Adegan Cerita}

Sebuah adegan cerita dihasilkan dari susunan komponen relief pada suatu panil relief, baik hanya satu komponen atau lebih. Susunan dari komponen-komponen relief yang telah diuraikan pada masing-masing panil berdasarkan munculnya kombinasi komponen relief yang sama menghasilkan 18 adegan cerita (lihat Tabel 4).

Tabel 4. Adegan Cerita Berdasarkan Kombinasi Komponen Relief

\begin{tabular}{|c|c|c|c|}
\hline No. & Adegan & Susunan Komponen & Kemunculan \\
\hline 1 & Pertarungan & $\begin{array}{l}\text { 1. Komponen tokoh yang membawa senjata } \\
\text { 2. Komponen tokoh yang membawa alat } \\
\text { perlengkapan perang } \\
\text { 3. Komponen senjata }\end{array}$ & $\begin{array}{ll}\text { - } & \text { Batu berelief } 1 \\
\text { Batu berelief 5 } \\
\text { panil A, B, D } \\
\text { Batu berelief } 8 \\
\text { panil B }\end{array}$ \\
\hline 2 & Pertapaan & $\begin{array}{l}\text { Komponen tokoh pertapa yang berada di } \\
\text { lingkungan pertapaan }\end{array}$ & $\begin{array}{l}\text { - } \quad \text { Batu berlief } 8 \\
\text { panil B } \\
\text { Batu berelief } 12 \\
\text { panil A }\end{array}$ \\
\hline 3 & Merindukan kekasih & $\begin{array}{l}\text { Komponen tokoh bangsawan ber-supit urang yang } \\
\text { sedang dalam sikap merindukan kekasih }\end{array}$ & $\begin{array}{l}\text { Batu berelief } 12 \\
\text { panil B }\end{array}$ \\
\hline 4 & $\begin{array}{l}\text { Kumpulan binatang } \\
\text { sawah }\end{array}$ & Komponen binatang yang berhabitat di persawahan & $\begin{array}{l}\text { Batu berelief } 10 \\
\text { panil A, B }\end{array}$ \\
\hline 5 & Kumpulan kerbau & Komponen binatang kerbau & $\begin{array}{l}\text { Batu berelief } 10 \\
\text { panil C, D }\end{array}$ \\
\hline 6 & $\begin{array}{l}\text { Pertemuan pertapa } \\
\text { dan Garuda di } \\
\text { dalam hutan }\end{array}$ & $\begin{array}{l}\text { 1. Komponen tokoh pertapa laki-laki } \\
\text { 2. Komponen tokoh Garuda } \\
\text { 3. Komponen tumbuhan berupa beberapa pohon } \\
\text { 4. Komponen binatang yang berhabitat di hutan }\end{array}$ & $\begin{array}{l}\text { Batu berelief } 8 \\
\text { panil B }\end{array}$ \\
\hline 7 & $\begin{array}{l}\text { Panakawan } \\
\text { membawa alat } \\
\text { musik }\end{array}$ & $\begin{array}{l}\text { 1. Komponen tokoh panakawan } \\
\text { 2. Komponen alat musik yang dibawa tokoh }\end{array}$ & $\begin{array}{l}\text { Batu berelief } 5 \\
\text { panil C }\end{array}$ \\
\hline 8 & $\begin{array}{l}\text { Bangsawan } \\
\text { diancam raksasi }\end{array}$ & $\begin{array}{l}\text { 1. Komponen tokoh raksasi yang sedang } \\
\text { menunjukkan sikap mengancam } \\
\text { 2. Komponen tokoh bangsawan bergelung supit } \\
\text { urang }\end{array}$ & $\begin{array}{l}\text { Batu berelief } 13 \\
\text { panil B }\end{array}$ \\
\hline 9 & $\begin{array}{l}\text { Bangsawan tidak } \\
\text { berdaya }\end{array}$ & $\begin{array}{l}\text { Komponen tokoh bangsawan bergelung supit urang } \\
\text { yang sedang berbaring }\end{array}$ & $\begin{array}{l}\text { Batu berelief } 13 \\
\text { panil C }\end{array}$ \\
\hline 10 & $\begin{array}{l}\text { Pertemuan } \\
\text { antarraksasa }\end{array}$ & Komponen tokoh raksasa yang saling berhadapan & $\begin{array}{l}\text { Batu berelief } 13 \\
\text { panil D, G, I }\end{array}$ \\
\hline 11 & $\begin{array}{l}\text { Pertemuan } \\
\text { bangsawan dengan } \\
\text { dewata }\end{array}$ & $\begin{array}{l}\text { 1. Komponen tokoh bangsawan laki-laki } \\
\text { 2. Komponen tokoh dewa atau dewi }\end{array}$ & $\begin{array}{ll}\text { - } & \text { Batu berelief } 7 \\
\text { - } & \text { Batu berelief } 13 \\
\text { panil A, E }\end{array}$ \\
\hline 12 & $\begin{array}{l}\text { Pertemuan } \\
\text { bangsawan dengan } \\
\text { raksasa }\end{array}$ & $\begin{array}{l}\text { 1. Komponen tokoh bangsawan bergelung supit } \\
\text { urang } \\
\text { 2. Komponen tokoh raksasa }\end{array}$ & $\begin{array}{l}\text { Batu berelief } 13 \\
\text { panil F, H, J }\end{array}$ \\
\hline
\end{tabular}




\begin{tabular}{|c|c|c|c|}
\hline No. & Adegan & Susunan Komponen & Kemunculan \\
\hline 13 & $\begin{array}{l}\text { Pertemuan dewa } \\
\text { dengan resi }\end{array}$ & $\begin{array}{ll}\text { 1. Komponen tokoh dewa } \\
\text { 2. Komponen tokoh agamawan (resi) }\end{array}$ & $\begin{array}{l}\text { Batu berelief } 8 \\
\text { panil A }\end{array}$ \\
\hline 14 & Iring-iringan & $\begin{array}{l}\text { Banyak komponen tokoh yang terlihat berjajar } \\
\text { dengan arah hadap yang bersamaan }\end{array}$ & Batu berelief 6 \\
\hline 15 & Menunggangi gajah & Komponen tokoh yang sedang menunggangi gajah & $\begin{array}{l}\text { Batu berelief } 3 \\
\text { panil A }\end{array}$ \\
\hline 16 & $\begin{array}{l}\text { Pertemuan } \\
\text { bangsawan dengan } \\
\text { tokoh yang } \\
\text { tergantung terbalik }\end{array}$ & $\begin{array}{l}\text { 1. Komponen tokoh bangsawan } \\
\text { 2. Komponen tokoh berbusana sederhana yang } \\
\text { sedang tergantung terbalik }\end{array}$ & $\begin{array}{ll}\text { - } & \text { Batu berelief } 4 \\
& \text { panil A } \\
\text { - } & \text { Batu berelief } 8 \\
\text { panil B }\end{array}$ \\
\hline 17 & $\begin{array}{l}\text { Garuda berdiri di } \\
\text { luar bangunan } \\
\text { tertutup }\end{array}$ & $\begin{array}{l}\text { 1. Komponen tokoh Garuda } \\
\text { 2. Komponen bangunan tertutup yang memiliki } \\
\text { pagar keliling yang dihias bilah tombak dan } \\
\text { roda }\end{array}$ & $\begin{array}{l}\text { Batu berelief } 8 \\
\text { panil A }\end{array}$ \\
\hline \multirow[t]{4}{*}{18} & Adegan lain & & \\
\hline & $\begin{array}{l}\text { Menampilkan satu } \\
\text { tokoh }\end{array}$ & & $\begin{array}{ll} & \text { Batu berelief 9 } \\
& \text { panil A, B, C, D } \\
\text { - } & \text { Batu berelief 11 } \\
& \text { panil A, B, D }\end{array}$ \\
\hline & $\begin{array}{l}\text { Menampilkan dua } \\
\text { tokoh }\end{array}$ & & $\begin{array}{ll}\text { - } & \text { Batu berelief } 4 \\
\text { panil B } \\
\text { Batu berelief } 11 \\
\text { panil C } \\
\end{array}$ \\
\hline & Tanpa tokoh & Tidak menampilkan komponen tokoh & $\begin{array}{l}\text { - } \quad \text { Batu berelief 3 } \\
\text { panil B } \\
\text { Batu berelief } 12 \\
\text { panil C }\end{array}$ \\
\hline
\end{tabular}

\section{Identifikasi Cerita}

Perbandingan adegan dengan naskah dan relief lain yang berkembang pada masa Majapahit dilakukan untuk mengidentifikasi sumber cerita. Dari 18 adegan cerita yang telah diketahui, hanya tiga adegan yang ditemukan perbandingannya dengan relief Majapahit lain, yaitu:

1. Adegan pertarungan yang menggambarkan dua tokoh saling memanah, yang berada pada panil B batu berelief 8 juga ditemukan di Candi Kedaton yang merupakan salah satu adegan dari cerita Arjunawiwaha.

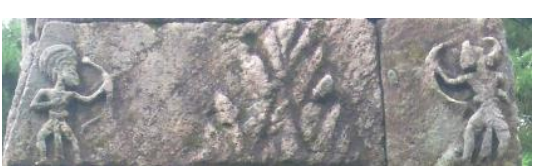

a

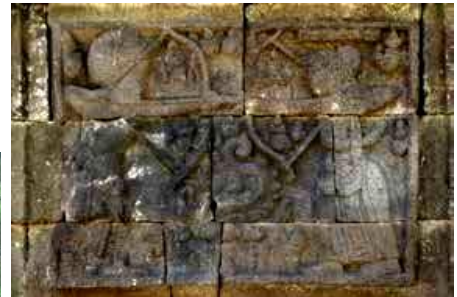

$\mathrm{b}$

Gambar 2. Adegan pertarungan pada panil B batu berelief 8 (a) dan Relief Arjunawiwaha Candi Kedaton (b) (Sumber: Dokumen Adwina (a); Sedyawati dkk., 2013 (b) 
2. Adegan bangsawan laki-laki diancam bangsawan raksasi dengan merentangkan tangan dan menudingkan jari ke arah sang bangsawan laki-laki, yang berada pada panil B batu berelief 13 paling mendekati penggambaran relief Sudamala yang terdapat di Candi Tegowangi.

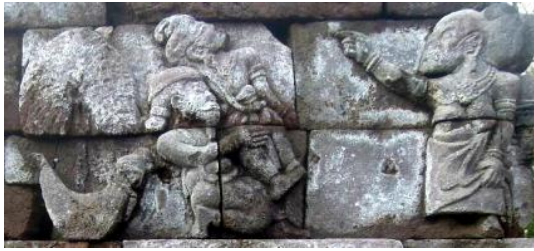

a

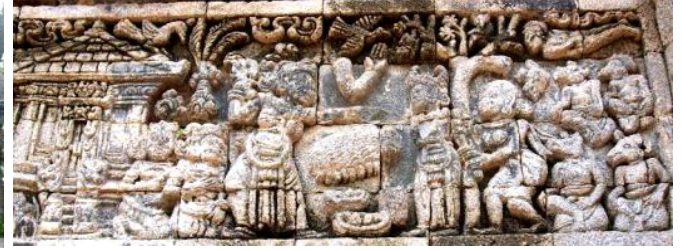

b

Gambar 3. Adegan bangsawan diancam raksasi pada panil B batu berelief 13 (a) dan Relief Sudamala Candi Tegowangi (b) (Sumber: Dokumen Adwina, 2014 (a); Alifah, 2014 (b)

3. Adegan pertemuan antarraksasa yang menggambarkan dua raksasa bangsawan dengan salah satu raksasa ditemani dua panakawan, yang berada pada panil $\mathrm{G}$ batu berelief 13, juga ditemukan di Candi Panataran yang menggambarkan cerita Ramayana.

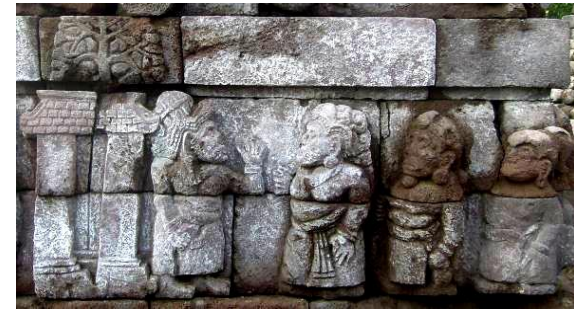

a

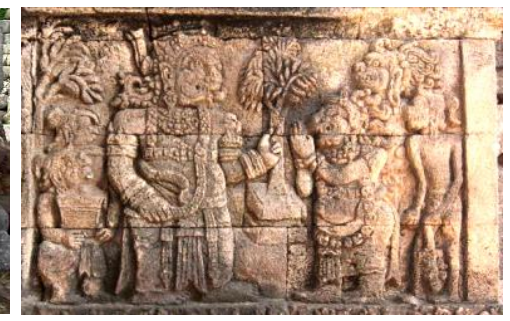

b

Gambar 4. Adegan pertemuan antar raksasa pada panil G batu berelief 13 (a) dan relief Ramayana Candi Panataran (b) (Sumber: Dokumen Adwina, 2014 (a); Rochman, 2015 (b)

4. Adegan pertemuan seorang bangsawan yang mengenakan gelung supit urang dengan seorang dewata digambarkan pada dua panil dalam satu batu berelief, yaitu panil A dan E batu berelief 13. Pada panil A menggambarkan bangsawan bergelung supit urang dalam sikap berlutut menyembah sang dewi yang ada di hadapannya dan ditemani seorang agamawan dan dua panakawan, relief ini paling mendekati penggambaran relief Sudamala di Candi Tegowangi. Sementara panil E menggambarkan bangsawan bergelung supit urang ditemani seorang agamawan dan seorang panakawan bertemu dengan seorang dewa, relief ini paling mendekati penggambaran relief Candi Sukuh lain yang telah diidentifikasi mengandung cerita Sudamala. 


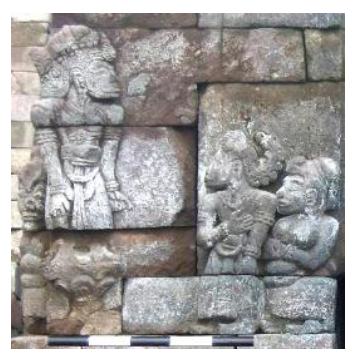

a

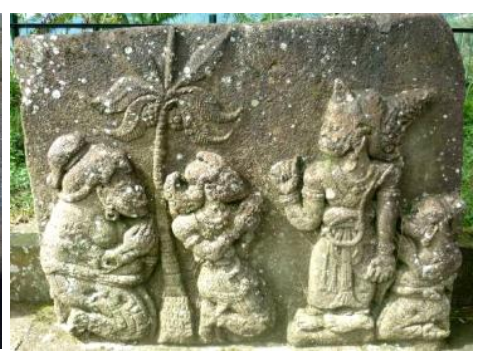

b

Gambar 5. Adegan pertemuan bangsawan dengan dewata pada Panil E batu berelief 13 (a) dan Relief Sudamala halaman teras III Candi Sukuh (b) (Sumber: Dokumen Adwina, 2014)

Selain dibandingkan dengan relief Majapahit lain, juga dibandingkan dengan naskah. Tidak semua yang tertulis dalam naskah dapat digambarkan pada relief karena sebagian besar relief merupakan relief adegan pandu, sehingga perbandingan dengan naskah cerita dapat diambil dari adegan yang paling mirip dengan penggambaran relief. Sebanyak sepuluh dari 18 adegan yang dapat dibandingkan dengan naskah cerita, yaitu:

1. Adegan pertarungan yang digambarkan pada tiga batu berelief, yaitu batu berelief 1 yang menggambarkan tokoh berbusana sederhana menunggangi kuda ditemani seorang pelayan pembawa payung dan dua prajurit yang membawa tombak, serta sekumpulan tombak lain yang berjajar paling mendekati penggambaran dalam cerita Panji ketika dilakukan penyerangan terhadap raja Bali (Poerbatjaraka, 1968: 189), kemudian panil B batu berelief 8 yang menggambarkan seorang tokoh pertapa dan seorang bangsawan laki-laki saling memanah ditemukan dalah cerita Arjunawiwaha ketika Arjuna sedang berhadapan dengan Dewa Siwa yang menyamar sebagai orang Kirata (Sedyawati dkk., 1979; Wiryamartana, 1990), serta pada panil A batu berelief 5 yang menggambarkan seorang bangsawan bergelung supit urang sedang akan melontarkan panah ditemani seorang prajurit membawa bendera perang yang bergambar Hanoman, dalam Wanaparwa disebutkan Hanoman akan berada dalam bendera perang milik Arjuna yang digunakan saat perang besar melawan Korawa (Roy, 1884: 323).

2. Adegan pertapaan pada panil B batu berelief 8 yang menggambarkan pertemuan bangsawan bergelung supit urang dengan Hanoman berpakaian seperti pertapa di lingkungan pertapaan, tidak ditemukan dalam karya sastra Jawa Kuno namun ditemukan pada salah satu parwa yang tidak ditemukan gubahannya dalam Jawa Kuno, yaitu cerita Wanaparwa ketika Bima yang telah diutus Dropadi untuk mencari bunga ke dalam hutan, berpapasan dengan seorang kera putih atau Hanoman (Roy, 1884: 310-323).

3. Adegan yang menggambarkan seorang pertapa laki-laki berhadapan dengan Garuda dalam sikap sedang terbang di dalam sebuah hutan dengan binatang-binatang hutan pada panil B batu berelief 8 paling mendekati cerita Garudeya ketika Garuda yang dilarang memakan para brahmana tidak sengaja menelan seorang brahmana yang kemudian dikeluarkannya kembali (Widyatmanta, 1968). 
4. Adegan yang menggambarkan seorang bangsawan bergelung supit urang yang sedang ditopang oleh seorang tokoh agamawan dan sedang diancam oleh seorang raksasi pada panil B batu berelief 13 paling mendekati cerita Sudamala ketika Sadewa diancam dan disiksa oleh Ranini (Padmapuspita, 1981: 64-110).

5. Adegan yang menggambarkan seorang bangsawan bergelung supit urang yang sedang diangkat oleh seorang raksasi kemudian adegan bangsawan yang sama sedang berbaring dan salah satu panakawan-nya sedang memijati kakinya pada panil C batu berelief 13 paling mendekati cerita Sudamala ketika Sadewa hampir tewas setelah disiksa oleh Ranini (Padmapuspita, 1981: 64-110).

6. Adegan pertemuan bangsawan dengan dewata digambarkan pada tiga panil. Yang pertama pada batu berelief 7 yang menggambarkan pertemuan Bima dengan seorang dewa serta adanya seekor ular berkepala dua yang berada di bawah mereka, maka cerita yang paling mendekati adalah cerita Bimasuci, versi lain Nawaruci, ketika Bima menang bertarung dengan ular raksasa kemudian di samudera Dewaruci menemui Bima (Prijohoetomo, 1934: 88-139). Yang kedua menggambarkan bangsawan bergelung supit urang yang ditemani seorang tokoh agamawan dan seorang panakawan berhadapan dengan seorang dewa pada panil E batu berelief 13 paling mendekati cerita Sudamala, ketika Siwa turun membantu Sadewa (Padmapuspita, 1981: 64-110). Yang ketiga menggambarkan bangsawan bergelung supit urang, ditemani seorang tokoh agamawan dan dua panakawan, berlutut menyembah di hadapan seorang dewi pada panil A batu berelief 13 paling mirip dengan cerita Sudamala, ketika Sadewa memberi sembah kepada Dewi Uma yang memberikannya anugerah (Padmapuspita, 1981: 64-110).

7. Adegan yang menggambarkan seorang dewa berlengan empat dan mengenakan serban ditemani seorang bangsawan laki-laki berhadapan dengan seorang resi yang ditemani dua bangsawan laki-laki pada panil A batu berelief 8 paling mendekati awal cerita dalam Bharatayuddha ketika Kresna datang ke Hastina dan diadakan pertemuan dengan Korawa (Sedyawati dkk., 1979; Zoetmulder, 1983: 323-332).

8. Adegan seorang tokoh berbusana sederhana sedang menunggangi gajah dan ditemani seorang pengiring yang membawa tongkat panjang tanpa tunggangan pada panil A batu berelief 3 paling mendekati cerita Panji ketika selesai mengunjungi Balambangan, Panji meneruskan perjalanan menggunakan kereta kencana dengan gajah (Poerbatjaraka, 1968: 189).

9. Pada panil A batu berelief 8, terdapat Garuda yang sedang menghadap ke sebuah bangunan tertutup yang dilindungi banyak bilah tombak sekelilingnya dan sebuah roda. Cerita yang paling mendekati dengan penggambaran relief tersebut adalah kisah Garudeya dalam Adiparwa, saat Garuda telah mencapai tempat air amrta setelah melewati para dewa yang menyerangnya dengan berbagai senjata. Setelah api yang melindungi persembunyian air amrta padam, terlihatlah sebuah roda besi yang sangat tajam (jantracakra) (Roy, 1884: 87-89; Widyatmanta, 1968).

10. Adegan lain yang menggambarkan seorang tokoh pada masing-masing panil berada pada dua batu berelief. Yang pertama pada panil B batu berelief 4 terdapat 
penggambaran Hanoman dengan semak-semak di depannya. Hanoman merupakan salah satu tokoh utama dalam cerita Ramayana (Sedyawati dkk., 1979; Zoetmulder, 1983; Santoso, 1980). Yang kedua pada batu berelief 9 yang memiliki empat panil yang masing-masing menggambarkan seorang tokoh, yaitu tokoh perempuan berbusana sederhana dengan rambut dikepang (panil A), tokoh bangsawan bergelung supit urang (panil B), tokoh panakawan (panil C), dan tokoh seorang raksasi dengan rambut dikepang (panil D). Dengan adanya tokoh-tokoh tersebut, maka sumber cerita yang paling mendekati adalah cerita Sudamala (Padmapuspita, 1981). Batu berelief 9 menggambarkan tokoh utama dalam cerita Sudamala, yaitu Ranini pada panil D, panakawan pada panil C, Sadewa pada panil B, dan Dewi Uma pada panil A.

\section{Sumber Cerita}

Melalui perbandingan terhadap naskah cerita, relief-relief pada bangunan suci lain yang semasa, serta penelitian-penelitian sebelumnya, maka dapat diidentifikasi delapan sumber cerita dengan tujuh adegan dalam cerita yang diketahui dan dua lainnya belum diketahui. Tujuh sumber cerita dengan adegan yang telah diketahui yaitu cerita Arjunawiwaha pada panil B batu berelief 8, cerita Sudamala pada batu berelief 9 dan empat panil batu berelief 13, cerita Bimasuci pada batu berelief 7, kisah Panji pada batu berelief 1 dan panil A batu berelief 3, kisah Garudeya yang ada dalam Adiparwa pada batu berelief 8 , cerita Bharatayuddha pada panil A batu berelief 8 , serta cerita Wanaparwa, yang tidak ditemukan gubahannya dalam karya sastra Jawa Kuno, pada batu berelief 8 . Sementara dua sumber cerita dengan adegan yang belum diketahui di antaranya cerita Ramayana pada panil B batu berelief 4 dan cerita Bharatayuddha pada batu berelief 5 .

Dengan demikan sebanyak lima batu berelief belum dapat diketahui sumber ceritanya, yaitu pada batu berelief 2 yang menggambarkan adegan kumpulan kerbau, batu berelief 6 menggambarkan adegan iring-iringan, batu berelief 12 menggambarkan adegan pertapaan dan merindukan kekasih, batu berelief 10 yang menggambarkan adegan kumpulan binatang sawah dan kumpulan kerbau, serta batu berelief 11 yang menggambarkan adegan dengan satu tokoh dan dua tokoh (lihat Tabel 5).

Tabel 5. Relief dengan Cerita yang Dapat dan Tidak Dapat Teridentifikasi

\begin{tabular}{cclll}
\hline No. & \multicolumn{1}{c}{ Letak } & \multicolumn{1}{c}{ Bentuk } & Sumber Cerita & \multicolumn{1}{c}{ Keterangan } \\
\hline 1 & Batu berelief 1 & Balok persegi & Kisah Panji & $\begin{array}{l}\text { Menggambarkan adegan kumpulan } \\
\text { kerbau. }\end{array}$ \\
\hline 2 & Batu berelief 2 & Balok persegi & - & \\
\hline 3 & Batu berelief 3 & Balok persegi & Kisah Panji & Menggambarkan adegan iring- \\
\hline 4 & Batu berelief 4 & Tembok & Ramayana & \\
\hline 5 & Batu berelief 5 & $\begin{array}{l}\text { Bongkahan } \\
\text { persegi panjang }\end{array}$ & Bharatayuddha & \\
\hline 6 & Batu berelief 6 & $\begin{array}{l}\text { Tembok } \\
\text { iringan. }\end{array}$ \\
\hline 7 & Batu berelief 7 & $\begin{array}{l}\text { Tapal } \\
\text { kuda/kala-mrga }\end{array}$ & Bimasuci & \\
\hline
\end{tabular}




\begin{tabular}{cllll}
\hline No. & \multicolumn{1}{c}{ Letak } & Bentuk & Sumber Cerita & \multicolumn{1}{c}{ Keterangan } \\
\hline 8 & Batu berelief 8 & Obelisk & $\begin{array}{l}\text { - Garudeya } \\
\text { - Bharatayuddha } \\
\text { - Wanaparwa } \\
\text { - Arjunawiwaha }\end{array}$ & $\begin{array}{l}\text { Satu adegan belum diidentifikasi } \\
\text { menggambarkan adegan pertapaan } \\
\text { dengan tokoh bangsawan bertemu } \\
\text { dengan tokoh yang tergantung } \\
\text { terbalik. }\end{array}$ \\
\hline 9 & Batu berelief 9 & Umpak & Sudamala & \\
\hline 10 & $\begin{array}{l}\text { Batu berelief } \\
10\end{array}$ & Umpak & & $\begin{array}{l}\text { Menggambarkan adegan kumpulan } \\
\text { kerbau dan kumpulan binatang } \\
\text { sawah. }\end{array}$ \\
\hline 11 & $\begin{array}{l}\text { Batu berelief } \\
11\end{array}$ & Umpak & & $\begin{array}{l}\text { Menggambarkan adegan dengan satu } \\
\text { tokoh dan dua tokoh. }\end{array}$ \\
\hline 12 & $\begin{array}{l}\text { Batu berelief } \\
12\end{array}$ & Tiang pendek & & $\begin{array}{l}\text { Menggambarkan adegan pertapaan } \\
\text { dan merindukan kekasih. }\end{array}$ \\
\hline & $\begin{array}{l}\text { Batu berelief } \\
13\end{array}$ & Candi kecil & Sudamala & $\begin{array}{l}\text { Lima panil bagian bawah } \\
\text { menggambarkan adegan pertemuan } \\
\text { bangsawan dengan raksasa dan } \\
\text { pertemuan antar-raksasa. }\end{array}$ \\
\hline
\end{tabular}

Terdapat lima adegan cerita yang memiliki penggambaran yang berbeda dengan naskah cerita, namun penggambaran relief tersebut dapat merepresentasikan adegan cerita. Perbedaan tersebut ditemukan dalam cerita Panji yang dipahatkan pada batu berelief 3, cerita Garudeya yang dipahatkan pada batu berelief 8 , cerita Bharatayuddha yang dipahatkan pada batu berelief 5 dan 8 , cerita Wanaparwa yang dipahatkan pada batu berelief 8 , dan cerita Sudamala yang dipahatkan batu berelief 13. Adanya perbedaan tersebut karena mungkin di lingkungan Candi Sukuh berkembang cerita dengan versi yang berbeda. Hal ini dapat didukung oleh hasil penelitian yang telah dilakukan oleh Nugraha (2012) terhadap prasasti-prasasti Candi Sukuh yang menyimpulkan bahwa lingkungan Candi Sukuh merupakan lingkungan kelompok para pujangga dan berbeda dengan lingkungan kerajaan.

\section{SIMPULAN}

Kisah yang digambarkan dalam 13 batu berelief Candi Sukuh berasal dari delapan sumber cerita. Delapan sumber cerita tersebut di antaranya Kisah Panji, Ramayana, Bharatayuddha, Bimasuci, Garudeya, Arjunawiwaha, Sudamala, dan Wanaparwa. Masing-masing batu berelief menggambarkan satu sumber cerita, kecuali batu berelief 8 yang berbentuk obelisk memiliki empat sumber cerita. Bila ditambahkan dengan kisah relief-relief yang teridentifikasi sebelumnya, maka terdapat dua sumber cerita yang paling banyak digambarkan di Candi Sukuh, yaitu Sudamala dan Garudeya.

\section{DAFTAR PUSTAKA}

Ayatrohaedi. (1981). Kamus Istilah Arkeologi I. Jakarta: Proyek Penelitian Bahasa dan Sastra Indonesia dan Daerah, Departemen Pendidikan dan Kebudayaan.

Crucq, K. C. (1936). Een Opmerking Over De Jaartallen Te Soekoeh En Tjeta. Tijdschrift voor Indische taal-, land- en volkenkunde, tijdschrift van het Bataviaasch Genootschap, bag. LXXVI, 337-339. 
Kempers, A. J. Bernet (1959). Ancient Indonesian Art. Amsterdam: C. P. J. Van der Peet.

Magetsari, N., Wibowo, A. S., Jafar, H., Ratnadi, I G., Sudhiono, S. K., \& Nurhadi, S. (1979). Kamus Arkeologi Indonesia 2. (Ayatrohaedi, Penyunt.) Proyek Penelitian Bahasa dan Sastra Indonesia dan Daerah, Pusat Pembinaan dan Pengembangan Bahasa, Departemen Pendidikan dan Kebudayaan.

Munandar, A. A. (2004). Karya Sastra Jawa Kuno Yang Diabadikan Pada Relief CandiCandi Abad ke-13-15 M. Makara, Sosial Humaniora, 8 (2), 54-60.

Munandar, A. A. (2011). Catuspatha, Arkeologi Majapahit. Jakarta: Wedatama Widya Sastra.

Nugraha, B. A. (2012). Prasasti-Prasasti Candi Sukuh: Suatu Tinjauan Aksara Dan Bahasa. Skripsi. Fakultas Ilmu Pengetahuan Budaya Universitas Indonesia, Depok.

Padmapuspita. (1981). Candi Sukuh Dan Kidung Sudamala. Proyek Pengembangan Media Kebudayaan, Ditjen. Kebudayaan Departemen Pendidikan dan Kebudayaan RI.

Poerbatjaraka. (1968). Tjerita Pandji Dalam Perbandingan. Djakarta: Gunung Agung.

Prijohoetomo. (1934). Nawaruci: Inleiding, Middel-Javaansche Prozatekst, Vertaling, Vergeleken Met De Bimasoetji In Oud-Javaansch Metrum. Groningen, Den Haag, Batavia: Bij J. B. Wolters' Uitgevers-Maatschappij.

Roy, P. C. (1884). The Mahabharata of Krishna-Dwaipayana Vyasa translated late English prose from the original Sanskrit text (Vol. 1-3). Calcutta: Oriental Publishing Co.

Santiko, H. (1995). Tokoh Bhima Pada Masa Majapahit Akhir. Dalam H. Soebadio, N. Soebagio, H. Santiko, R. F. Nurlambang, A. A. Munandar (Penyunt.), Kirana: Persembahan untuk Prof. Dr. Haryati Soebadio (hal. 123-138). Jakarta: PT Intermasa.

Santiko, H. (2011). The Role of Bhima at Candi Sukuh. Amerta, Jurnal Penelitian Dan Pengembangan Arkeologi, 29 (2), 18-26.

Santoso, S. (1980). Indonesian Ramayana (Vol. 1-2). New Delhi: Sharada Rani, Hauzkhas Enclave.

Satari, S. S. (1999). Teknik Analisis Relief. Dalam Soeroso, Teknik Analisis Arsitektur Candi (hal. 1-8). Lembang: Evaluasi Hasil Penelitian Arkeologi.

Sedyawati, E., Subroto, P.H., Wahyati, P., Kusparyati, B., Maulana, R. (1979). Keterangan Ikonologis dari Sumber-Sumber Pustaka Jawa Kuna. Laporan Penelitian. Fakultas sastra-Universitas Indonesia.

Sedyawati, E., Santiko, H., Djafar, H., Maulana, R., Ramelan, W. D., Ashari, C. (2013). Candi Indonesia seri Jawa. Jakarta: Direktorat Pelestarian Cagar Budaya dan Permuseuman, Direktorat Jenderal Kebudayaan, Kementerian Pendidikan dan Kebudayaan.

Sharer, R. J., \& Ashmore, W. (2003). Archaeology Discovering Our Past (3 ed.). McGraw-Hill. 
Stutterheim, W. F. (1930). Gids Voor de Oudheden van Soekoeh en Tjeta. Soerakarta: De Bliksem.

Stutterheim, W. F. (1956). Studies in Indonesian Archaeology. The Hague: Martinus Nijhoff.

Subroto, P. (1977). Kelompok Kerja Pandai Besi Pada Relief Candi Sukuh. Pertemuan Ilmiah Arkeologi. Proyek Penelitian dan Penggalian Purbakala, Departemen Pendidikan dan Kebudayaan, Cibulan.

Suhadi, M., Ferdinandus, P. E., Amelia, \& Indrajaya, A. (2000). Penelitian Arsitektur di Kabupaten Karanganyar, Provinsi Jawa Tengah. Jakarta: Pusat Arkeologi, Departemen Pendidikan Nasional.

Widyatmanta, S. (1968). Adiparwa. Jogjakarta: U. P. Spring.

Wiryamartana, I. K. (1990). Arjunawiwaha: Tranformasi Teks Jawa Kuna Lewat Tanggapan Dan Penciptaan di Lingkungan Sastra Jawa. Yogyakarta: Duta Wacana University Press.

Zoetmulder, P. J. (1983). Kalangwan Sastra Jawa Kuno Selayang Pandang. (D. Hartoko, Penterj.) Jakarta: Djambatan. 


\section{Lampiran.}

Tabel 5. Jumlah Kemunculan Komponen-komponen Tokoh pada Tiap Panil Batu Berelief

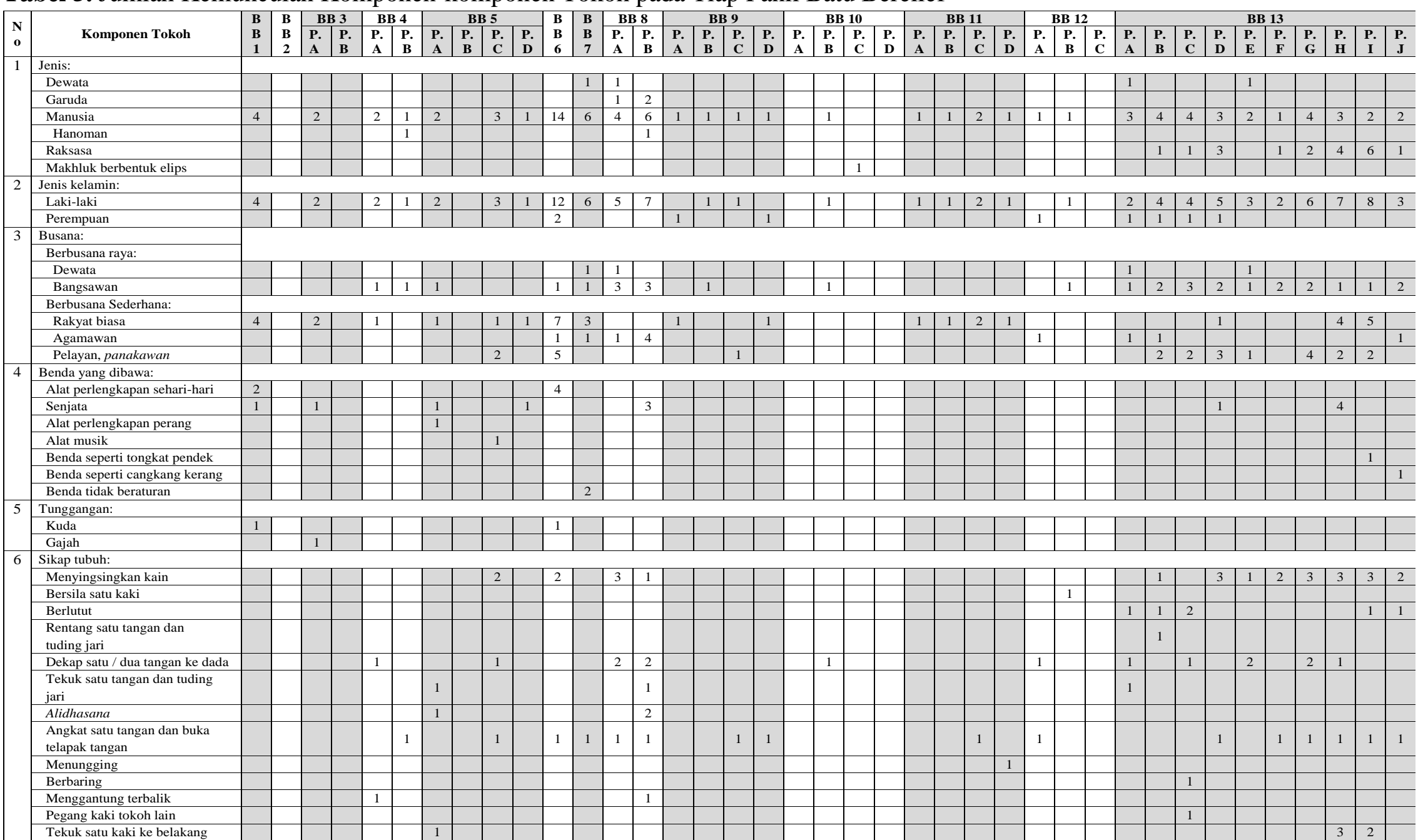

Keterangan: $\mathrm{BB}=$ Batu berelief; $\mathrm{P} .=$ Panil. 